A patient has heavy and long menstrual cycles. The problem is eventually diagnosed as fibroids. After some time trying depo-provera, she becomes severely anaemic and is admitted to a hospital emergency ward. The doctors agree on the need for a partial hysterectomy. Nevertheless, there is a chemical option, which aims to shrink the fibroids, and which in all honesty the doctors must explain to the patient. This treatment has serious side effects, and the fibroids may still return. Switankowsky asks us to imagine two women reflecting upon these choices. Woman A chooses the surgery, Woman B chooses the medication. Which, asks Switankowsky, chooses rationally, and hence can genuinely consent?

For Switankowsky the correct answer is Woman A. A recognises that partial hysterectomy is the medically rational thing to do; she does not let other issues cloud her judgment. Woman B, however, chooses the chemical treatment. She is worried about her femininity, and is quite unreasonably swayed by the recent death of a close relative on the operating table. Switankowsky comments that if B just stepped back for a moment, she would see that, at 37 , she shouldn't try to have more children, and that the minuscule chances of dying under anaesthetic should have no bearing upon her decision. $B$ is irrational, she cannot genuinely choose the chemical option.

What seems to lead to the conclusion that B is irrational is Switankowsky's inability to see that anything other than medical matters could be relevant in such cases. Whatever is medically indicated must be the rational choice. One is tempted to respond, perhaps, that B's values are different from A's. That for B, but not for A, femininity does matter. Switankowsky seems committed to saying either that such matters are irrelevant, or that B does not know her own values or does not know them deeply or adequately, or that she has the wrong values. It appears that in Switankowsky's treatment of this case, medical paternalism, having apparently been shown the front door, has walked boldly in again at the back. Decisions must conform to the patient's values; but on pain of incompetence, the patient's values must be medical values.

Switankowsky does have a response, but it seems to be purely verbal in character. Within the "autonomy en- hancing model", the physician cannot persuade, coerce, manipulate, or decide for a patient, however irrational. But she can, and should, guide the patient. This central notion of "guidance" is not indexed, but seems to consist of getting the patient to look again at her decision, helping her to "stand back" and realise she has been irrational. That the appeal to guidance is a merely verbal manoeuvre appears if we imagine the doctors guiding $B$. Since, according to Switankowsky, it is in part the content (as opposed to the process) of B's decision which is the problem, we can judge that she has been guided only when she changes her decision to the one her surgeon considers rational. Medical paternalism is dead; long live medical paternalism.

Switankowsky's treatment of cases is in tension with the rhetoric of the "autonomy enhancing model" of informed consent she proposes. Her book, far from achieving its avowed purpose, tends to reproduce the gap between the rhetoric and the practice of informed consent which it purports to bridge.

NEIL PICKERING,

Centre for Philosophy and Health Care, University of Wales Swansea

\section{Who Goes First? The Story of Self-experimentation in Medicine}

Lawrence K Altman, California, University of California Press, 1998, 430 pages, $\$ 17.95$.

This is the paperback edition of a book that was first published in 1987. In his preface, the author stresses that in the USA the issue of self-experimentation and the choice of the first human volunteer has not been seriously addressed. He goes on: "This dearth of attention reflects medicine's apathy towards its own history which is rich in fascinating and instructive stories about self-experimentation". Altman is clearly fascinated by this topic and has studied it for 30 years. The book, which is well researched and informative, is written for the general public, but will also be of interest to medical students and doctors with an interest in medical history.

Faced with a deadline and not wishing to spoil a good read, I have based my comments on the first eight of 15 chapters, and the final chapter. As yet unexplored are chapters on dietary deprivations; lifetimes of selfexperimenting; the red cell riddle; cancer; "black and blue at the flick of a finger", and choosing the right animal. Altman, a clinical associate professor of medicine, is also medical correspondent of the New York Times, and uses alluring chapter headings.

Six chapters are devoted to various infectious diseases. They describe topics as varied as early attempts to develop vaccines, and the discovery that mosquitoes are the vector for yellow fever. Altman is at some pains to demonstrate that Dr Walter Reed who was credited with this discovery, played a less than noble part in the work. Having persuaded his colleagues to self-experiment, he removed himself from the scene with alacrity, leaving them to risk their lives. One, Dr Carroll, contracted yellow fever but survived. Another, Dr Lazear, died, attended by Professor William Osler in 1900. This book brings medical history alive!

In a chapter on parasitic diseases we are told that $97 \%$ of world finance for biomedical research is spent on health problems in developed countries. A note at the back of the book mentions that parasitic diseases are largely responsible for the 30-year difference in life expectancy between people in developed and underdeveloped countries. A point such as this deserves mention in the main text, and some ethical exploration.

I found the arrangement of the book slightly irritating. A prologue of 13 pages precedes the main text (303 pages), which is followed by 100 pages of notes. Much of interest is written in the notes, but reading them in context involves endless to-ing and fro-ing.

Not being a medical historian, much of the information was new to me, and much was fascinating. I empathised with Werner Fossman, a young German doctor, who was excited by the possibility of placing a catheter in the human heart. He showed pictures from a veterinary text to his consultant, who forbade him to try the technique on himself. He went ahead in secret, and in 1929, threaded a catheter through the brachial vein into his right atrium, then walked down to the basement to get a horrified technician to take an X-ray, which proved the point. Later he pioneered angiocardiography on himself. His work, though unrecognised at the time, later won him a Nobel prize. His career was disrupted by the 
second world war. Although a Nazi, he refused to experiment on helpless human guinea pigs, saying this was a price he would never pay for the realisation of his dreams. Those in the UK who seek to change the law to allow experimentation on patients with mental incapacity, without their consent, would do well to follow his example. This is a particularly fraught area of medical ethics, and any such research should only be done if it is likely to be of some benefit to the patient.

Another fascinating chapter is about the development of anaesthetics. An English clergyman, and accomplished chemist, Joseph Priestley, prepared pure oxygen and nitrous oxide back in 1774. Then he inspired Dr Thomas Beddoe to found the Medical Pneumatic Institution, and Humphrey Davy was appointed first director. Davy tried nitrous oxide on himself and discovered its analgesic properties, but doctors ignored his findings for 40 years.

People lived dangerously in the past but the lack of regulation enabled inspired individuals to explore their creativity in freedom. There are many stories of courage and daring in the book, not least that of Dr Frederick Prescott of Burroughs Welcome, who in 1944 consented to be the human guinea pig for curare.

There are nuggets of interest to medical ethicists in the book, but you have to discover them for yourself. It is not primarily a book about medical ethics. Some eloquent quotes come from Dr Stephen Elek, once professor of bacteriology at St George's Hospital, London. He said: "If anything goes wrong and the skid row bum dies, and the experimenter has not done it on himself, he is liable for murder. It's as simple as that. A man is entitled to risk his own life. He is not entitled to risk somebody else's".

In the final chapter, Altman looks at what motivates people to experiment on themselves. He also considers the limitations of self-experimentation. He stresses that the risk of performing an unethical human experiment is enormous. Increased attention to the question of who goes first, he argues, would improve the quality of the informed consent process that the Nuremberg Code has made mandatory.

\section{Ethics and Values in Health Care Management}

\section{Edited by Souzy Dracopoulu, Lon- don, Routledge, 1998, 200 pages, $£ 14.99$.}

This book aims to present an "up-todate-analysis of the relationship between ethics and management of the health care services". This includes a debate about the status of ethics in health care management. In addition it offers studies of health care reform related to value criteria in Poland, France and Greece.

Loughlin produces a spirited attack on the view that an ethic for managers can be constructed. His complex case involves two related arguments. First, that this enterprise is inextricably bound up with demands for rationing which treat socially generated scarcity as natural. Second, that the correct standard for ethical reasoning requires a level of deductive proof which is unavailable to those who treat the present structure of liberal democracies as a given. In conducting his attack he examines arguments, published elsewhere, made by contributors to this volume such as Andrew Wall, former health services manager and author of one of the all too rare books on health care management ethics and Alan Williams, defender of the QALY (Quality Adjusted Life Year). None of the contributors discuss one another's arguments as presented here. This is a shame as direct engagement amongst the contributors would have given us sharper definition of the issues. The very important points presented by Loughlin that every would-be manager and every philosopher serving on quangos should have to consider, jostle next to his arguments about social policy formation that do not get the adversarial attention they warrant.

Wall presents an accessible runthrough of ethical issues a senior manager might come up against including: research, purchasing decisions and termination of active treatment. $\mathrm{He}$ notes that managers are not bound by professional discipline, that "anyone can become a health services manager" and that ethics is not synonymous with law. Since Wall has argued that managers should treat patients as bearers of rights and has acted on this in practice, his statement of principles should not be dismissed by Loughlin as so general that "no-one in their right mind could disagree with them: Utilitarians disagree with Wall at the conceptual level, and local campaigi ers committed to maintaining the value of their property can make 1 ese difficult for a manager committed $\$$ implementing service plans designed to protect "rights" of people with mental health problems.

Loughlin asserts that role definitions lock managers into organisationg imperatives which cannot accomm date need. In contrast, Chadwi insists that there are ethical ambigivio ties endemic to deliberate decision making in any complex society which are distinct from questions aboif rationing. She shifts discussion from managers to the management fun tion, starting with National Health Service (NHS) goals which give specta weight to justice, efficiency and accep ability to users. An approach co cerned to maximise the health of the community rather than one to promoses the flourishing of individuals appears to fit with these goals. But she noteg that the provision of information, as the case of genetics services, is requirement, understandable within virtue ethics approach, explicitly eक्षे chewing population health outcomes.

The three European case studie supply ample evidence of pervasice non-rational social factors whic shape attempts to improve regulation of their health care systems. They tre the strengthening of the manageme function as essential to giving weigf to ethical concerns. The Europea contributors, along with Loughlip, present a challenge: are managers equipped with the broad, multidisci plinary knowledge base, including humanities and social sciences, enable them to make their way respore sibly through these issues?

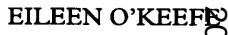

School of Health Studies University of North Londow

Informed Consent in Psychiatry: European Perspectives of Ethics Law and Clinical Practice

Edited by $\mathrm{H}$ Koch, S Reiter-Theil and $\mathrm{H}$ Helmchen, Baden-Baden, Nomos Verlagagesellschaft, 1996, 42 pages, 88DM. 